\title{
Effects of Talent Management Practices on Organizational Engagement: A Quasi- Experimental Study
}

\author{
Selman TETIK ${ }^{*}$, Halil ZAIM**
}

Received: April 11, 2021

Revised: May 30, 2021

Accepted: May 31, 2021

\begin{abstract}
Talent management (TM) is considered a strategic tool to gain a sustainable competitive advantage for organizations. This study aims to explore the effects of TM practices on the engagement level of employees. A field study has been conducted within a Turkish holding to analyze the effects of TM. However, the scope of the study is restricted to the administrative departments within the headquarters of the holding. A quasi-experimental design is developed to conduct the research, and two groups are designated as the talent and the control groups for the study. Data is collected via surveys on the members of both groups before and after the intervention. Interviews are conducted during the intervention process, a talent matrix and a talent grid are developed, and the development practices are offered and partially implemented. In order to investigate the impact of TM on employees' organizational engagement, the means (averages) of two groups are compared before and after the implementation of TM program. We tried to determine if the difference is statistically significant or not. The research findings reveal a significant difference in the employees' organizational engagement level between the talent group and control group before and after the implementation of TM program. This result indicates that TM strategy has a significant positive impact on employees' engagement.
\end{abstract}

Keywords: Resource-based view, Talent management, Organizational engagement, Quasi-experimental design, Human Resource Management

JEL Code Classifications: D23, J24, O15

UDC: 334.025

DOI: https://doi.org/10.17015/ejbe.2021.027.06.

\footnotetext{
* PhD, Lecturer, School of Business and Creative Industries, The University of the West of Scotland, UK. E-mail: selman.tetik@uws.ac.uk

** Professor, Independent Researcher, USA, E-mail: halilzaim1974@gmail.com
} 


\section{Introduction}

Over the past decade, organizations have been operating in a fast and continuously changing environment. To compete in this dynamic, turbulent environment, organizations need to pay more attention to quality, cost, and agility at higher levels (Hadziahmetovic et al., 2017; Dahou \& Hacini, 2018; Harsh \& Festing, 2020). However, the resources should be long-lived and cannot be replicable (Heinen \& O'neill, 2004; Mattone \& Xavier, 2012). In the knowledge economies where knowledge is a significant component of value creation, organizations are increasingly counting on the contributions of talented employees (Nonaka, 2005; Zaim et al., 2018). Therefore, a talent management strategy is needed to gain sustainable competitive advantages in this competitive environment (Waheed et al., 2012; Gallardo-Gallardo et al., 2020).

In order to understand the development in Human Resources Management (HRM), the evolution of management thought should be overviewed. Historical developments in the management field have indicated paradigm shifts in people at work. People were assessed as a cost, and the human factor was ignored in workplaces. The formal transactions, such as payment and disciplinary issues, were of 'personnel management through the perspectives of scientific management. That resulted from a massive transformation that was the industrial revolution, that changed employees' habits in their work lives (Tetik, 2016). Over time, the position and contribution of people gained significant importance in workplaces, and HRM practices have been diversified to appreciate and retain qualified people (Azmi, 2008).

In the literature, there are several approaches to define talent management. Three perspectives on talent management are by Lewis and Heckman (2006). HRM practices such as recruiting, selection, development, and succession planning are included in the first perspective of Lewis and Hackman. The focus of the second approach on talent management is talent pools. In this approach, an employees' needs and managing the development processes of employees through the positions are evaluated. The focus of the third perspective is on the talent within organizational boundaries or specific positions. There are two general approaches to the talent concept in this perspective. Talents are defined as high performers and high potentials, and these people are considered unlabored resources in the first approach. Thus, it is highly recommended to manage those talents' performance in their positions (Lewis \& Heckman, 2006). In the second approach, talents are assessed as a source of competitive advantage of the organization, and it is placed within the organization's strategic planning process (Hughes \& Rog, 2008).

Concerning all the perspectives discussed above, this study has designed and developed a talent management process, which includes identifying the high potential and high performer employees, creating a talent pool, providing development practices, and designing retention practices. This study's talent 
management implementation has been held within the headquarter of a holding in Turkey. Holding decided to change their mindset on HR policy and practices and began to implement different HR processes like performance management system, defining the competencies of the holding, and developing a talent management system simultaneously.

Even though several studies have been made on talent management, more empirical studies are needed to generate different perspectives on talent management (Lewis \& Heckman, 2006; Collings \& Mellahi, 2009; Thunnissen et al., 2013; Al Ariss et al., 2014). This study provides a field study with new perspectives for the academic literature and practitioners. The experimental field study which is used in this study facilitates the exploration of new perspectives.

This study aims to reveal the impact of talent management practices on organizational engagement. Accordingly, a field study is conducted by designing a talent management program in a Turkish Holding. That specific holding is chosen due to their request and willingness to implement a TM program. Moreover, that holding, composed of 23 companies operating in 16 different industries, employs over 8000 employees. Therefore it was an ideal sample for a quasi-experimental design and research like this. On the other hand, one of the purposes of implementing TM is to foster employees' organizational engagement. Furthermore, the effects of this TM program are achieved by comparing the results between two groups of employees who participated in the program and those who have not.

\section{Literature Review}

\subsection{Talent Management}

The first discussion of talent began with the "war for talent" by McKinsey in 1997 (Chambers et al., 1998: 45). Then, the interest of the scholars and practitioners reverted to talent management (Axelrod et al., 2001; Collings \& Mellahi, 2009). This movement of interest has also created a new paradigm that has stressed the importance of talent management (Collings \& Mellahi, 2009).

According to Sparrow et al. (2014), Talent Management is an anchor to bridge the perspectives and practices from different fields, including HRM, supply chain management, and capability theory resource-based view.

The companies could facilitate firm-specific competencies by adapting HRM based on the resource-based view (Lado \& Wilson, 1994). This effort has led companies to develop organizational competencies concerning the objectives of the organizations. As it becomes the focus of the companies, Talent Management is seen as a strategic approach (Boudreau \& Ramstad, 2005; Collings \& Mellahi, 2009; Gallardo-Gallardo et al., 2020).

There are several talent management systems as proposed in the literature. In this study, Berger and Berger's (2004) TalentReservoir ${ }^{\circledR}$ approach and Schiemann's 
(2014) talent management lifecycle are used as the model. In Berger and Berger's (2004) model, the talent system is defined by three components; -Designing and building a TalentReservoir ${ }^{\circledR}$ solution, capturing the TalentReservoir ${ }^{\circledR}$ solution in a software package, and implementing an integrative TalentReservoir ${ }^{\circledR}$ process. $^{-}$ According to Schiemann's (2014) talent management lifecycle, there are stages of interaction and connection within the organization by implementing the attracting, acquiring, onboarding stages.

Based on those models, talent management can be described as defining, developing, and retaining the organizations' competitive edge. The defining process includes the practices of attracting, acquiring and identifying, and developing a talent pool. The development process consists of training, coaching, mentoring, career management, and leadership development. The retaining process covers performance management, succession planning, compensation, and advancement opportunities. TM practices have been taken in three main processes: defining, developing, and retaining talents. However, practices for developing Talent Pool are the main focus of the study.

\subsection{Organizational Engagement and Talent Management}

A growing body of studies associates and reveal the relationship between talent management and employees' organizational engagement practices. An effectively implemented talent management strategy can result in effective recruitment and retention of employees and enhanced organizational engagement (Hughes \& Rog, 2008; Glavas, 2012; Alias et al., 2014; O'Connor \& Crowley-Henry, 2019). Employees' organizational engagement is considered a critical factor in retaining talent and motivating people (Hughes \& Rog, 2008; Blass, 2009; Alias et al., 2016). The engagement can also be supported by development, leadership effectiveness ( Butler \& Waldrop, 2004; Barrick et al., 2015), and relational creativity (Bhatnagar, 2007). Leaders can improve the performance of the organization by ensuring the engagement of the organization's members. Internal capabilities should be developed to improve employees' organizational engagement (Barrick et al., 2015; Goestjahjanti et al., 2020). Likewise, organizational engagement and talent management strategy are mutually connected and related practices. One way of having a successful talent management strategy requires that employees feel "connected" or engaged to their job and organization.

It is suggested that effective talent management policies and practices result in more engaged employees and lower turnover by ensuring the commitment to human capital (Hughes \& Rog, 2008; Pandita \& Ray, 2018). Retention is one of the critical concerns in a talent management process, and it is supported by many studies in which more engaged employees are more likely to desire to stay on the job (Bakker, Demerouti, De Boer \& Schaufeli, 2003; Schaufeli \& Bakker, 2004; Hallberg \& Schaufeli, 2006). One of these studies, conducted by the Corporate Leadership Council, demonstrates the connection between engagement to business success and 
its direct impact on employee performance and retention, and it also shows the contribution of managers to enhance employee commitment to the organization, job, and work teams (Lockwood, 2007). Even though theoretically, the link between talent management and organizational engagement is well acknowledged, there is limited empirical evidence revealing the relationship between retention and engagement. Therefore, there is a need for more empirical studies in the literature to support the positive effect of talent management on employees' organizational engagement.

The studies were conducted on employees' organizational engagement by developing different perspectives. Several conceptual models aim to identify links between conditions, characteristics, and consequences of engagement in the literature (Kahn, 1990, 1992; Robinson et al., 2004; Saks, 2006; Macey \& Schneider, 2008; Shuck et al., 2011; Christian et al., 2011). Beyond these studies, some of the research reveals that job resources, such as social support from colleagues and supervisors, performance feedback, skill variety, autonomy, and learning opportunities, positively influence work engagement (Bakker et al., 2008). Besides that, there is a shift in studies to improve employees' organizational engagement (Sambrook et al., 2014). Likewise, in their diagnosis, Christian et al. (2011) and Sambrook et al. (2014) state that few researchers can reflect the multidimensionality of engagement within people or between levels in an organization or sector, despite the consensus among scholars that employees' organizational engagement is considered a multi-dimensional and dynamic concept. Hence, more studies are needed to fill the gap in the research associated with HR. The studies should focus on aspects like the HR understanding of $E E$, the formulation and implementation of EE strategies by $H R$, how these are received, and the effect on senior, local line management, trade unions, and the employees within organizations. From the HR point of view, this constitutes a research gap. Therefore, by evaluating the positive association of job resources with job satisfaction and considering the tendency towards improving engagement at the organizational level, in this study, we propose an approach to improve work engagement by implementing talent management within an organization. As previously stated, job resources such as support from peers and supervisors, learning opportunities, and performance feedback facilitate and mediate work engagement. Talent management practices include different actions such as mentoring, coaching, training, career development, and rewarding. So, it appears that those actions can positively affect engagement.

\section{Research Design and Methodology}

In this study, a talent management program is designed, developed, and implemented. The effects of that program on employees' organizational engagement are then evaluated. Even though many studies depict the dimensions of talent management, there is still a lack of unity and consensus on the overall dimensions of talent management. By implementing a talent management program 
directly, like taking the explorer role of the researcher (Brown, 2006), this study aims to recognize unarticulated dimensions within the organization. By doing so, it may be possible to extend the literature by gathering new information and knowledge. That is why this research can yield an action/applied research method in the first phase of the study since action/applied research is an appropriate method while influencing planned interventions and modifications ( Sekaran, 2003; Saunders et al., 2009).

In the second phase of this study, the effects of talent management have been examined based on data collected from the participants of the talent group and the control group via a self-administrative questionnaire.

\subsection{Survey Instrument}

The survey instrument is a self-administered questionnaire composed of 16 questions; 5 are demographic questions, the remaining 11 aim to reveal the employees' organizational engagement. Organizational engagement questions are derived from Esen (2012). The original questionnaire consists of 15 items with a sixpoint rating scale, ranging from almost never (1) to almost always (6). In this study, 15 items have been slightly changed, and the number of the items on the scale has been decreased to 11. Each item is rated on a five-point Likert Scale anchored at the numeral 1 with the verbal statement "strongly agree," At the numeral 5, the verbal statement "strongly disagree."

\subsection{Sample}

The talent management program has been conducted in a Turkish Holding in Istanbul. The holding is composed of 23 companies in 16 different industries and employs more than 8000 employees. However, the data for this study are collected from the headquarters office, where nearly 350 employees and managers are working. The data collected are from two groups:

The talent group: This group is composed of employees who are involved in the talent management program.

The control group: This group comprises employees who are not involved in the talent management program.

Random selection is deemed not appropriate for this study by its nature. Therefore, a convenient sampling method has been used to determine the participants. Accordingly, only the members of the administrative department within the headquarter of the holding are involved in the data collection. A total sample of 35 participants is involved in the talent group, and 33 employees are involved in the control group. Considering the number of employees is nearly 350 in the headquarters office, the number of talent and control group nearly $10 \%$ for the sampling is regarded as a good sample size (Gable, 1994). Both groups are with similar qualifications. During the process, some of the incumbents left the holding 
for various reasons. Therefore, only 25 participants were left for the talent group and 32 for the control group for the second survey.

\subsection{Analysis}

The questionnaires were sent to the talent management group and control group work in the General Administration departments of the holding.

In the analysis, the means (averages) of the two groups are compared. The analysis focuses on whether the difference is statistically significant or not. The descriptive statistics of the data are provided in the following tables.

In the talent group, $54.3 \%$ of the participants are between 20 and 30; $45.7 \%$ are between 31 and 40 years old. 74.5\% have up to 5 years of experience, 20\% have 6 to 10 years of experience, and $5.7 \%$ have 11 to 15 years of experience. $71.4 \%$ of the participants have a bachelor's degree, $25.7 \%$ have a master's degree, and $2.9 \%$ have Ph.D.

The second group is the control group, and the descriptive statistics of the initial measurement are named the control group.

In the control group, $40.6 \%$ of the participants are between 20 and 30 years old, $53.1 \%$ are between 31 and $40,6.3 \%$ are over 41 years old. 46.9 of the group members have experience between 1 and five years, $28.1 \%$ of the group's experience between 11 and $15.90 .6 \%$ have a bachelor's degree, and $9.4 \%$ of the group have a master's degree.

There are no significant differences between the talent and control groups before the intervention regarding the demographic structure such as age, experience, and education.

In the analysis, the data is examined to determine whether it is parametric or nonparametric. Parametric or nonparametric tests are used to check the difference between the talent group before and after the intervention. If the data is distributed, a parametric test (independent t-test) is used, but a nonparametric test (Mann Whitney $U$ test) is used if the data is not normally distributed. Hence, the normality of data uses Kolmogorov Smirnow test. Firstly one of the measured variables, 'engagement data,' was analyzed in normality, and engagement scores are normally distributed ( $p$-value: 0.447$)$. Therefore, the parametric test is appropriate for the application. Parametric statistics are viewed as more potent because they use numerical data (Saunders et al., 2009).

HO: Engagement data is normally distributed

$\mathrm{H} 1$ : Engagement data is not normally distributed

Since normality tests in Table 1 indicate the normal distribution of the data, the independent t-test is used as the parametric statistics to evaluate the groups' differentiation which helps to compare the difference in the means of the two groups 
using a measure of the spread of the scores (Saunders et al., 2009). By doing that, the likelihood of any difference between these groups is determined. A significant $t$ statistic can indicate it with a probability of less than 0.05 refers that the difference between the groups is statistically significant (Saunders et al., 2009).

Table 1. Normality Test of Engagement

\begin{tabular}{llr}
\hline $\mathrm{N}$ & & 125 \\
\hline Normal Parameters & Mean & 3.7484 \\
\hline & Std. Deviation & 0.67609 \\
\hline Most Extreme Differences & Absolute & 0.077 \\
\hline & Positive & 0.043 \\
\hline & Negative & -0.077 \\
\hline Kolmogorov-Smirnov Z & & 0.862 \\
\hline Asymp. Sig. (2-tailed) & & 0.447 \\
\hline${ }^{a}$ Test distribution is Normal ${ }^{b}$ Calculated from data.
\end{tabular}

a Test distribution is Normal. ${ }^{\text {b }}$ Calculated from data.

The first analysis has been performed to examine the difference between the talent and the control groups before implementing the talent management practices. As seen in Table 2, there is no considerable difference between the talent group and control group before the intervention, and the difference is not statistically significant. It is depicted in Table 3.

Table 2. Group Statistics of Talent and Control Pre-test Groups in Engagement

\begin{tabular}{llcccc}
\hline & Group & $\mathrm{N}$ & Mean & Std. Deviation & Std. Error Mean \\
\hline \multirow{2}{*}{ Engagement } & Talent Group Pre-test & 35 & 3.5429 & 0.56708 & 0.09585 \\
\cline { 2 - 5 } & Control Group Pre-test & 32 & 3.6676 & 0.73079 & 0.12919 \\
\hline
\end{tabular}

\section{Table 3. Independent Samples Test of Engagement for Talent and Control Groups Pre-test}

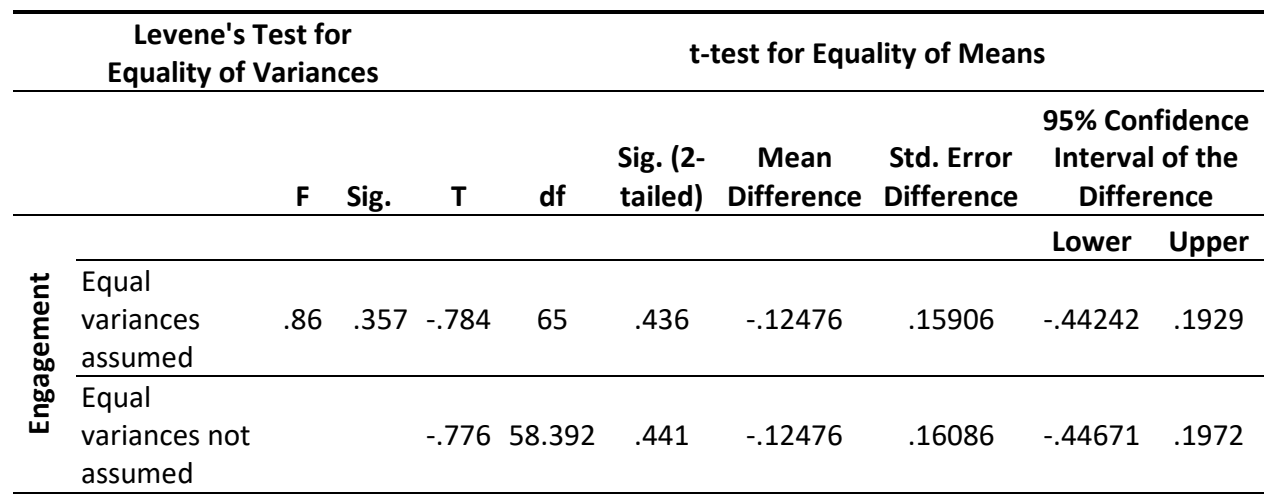

$\mathrm{HO}$ : The engagement level of the talent group is not different from the engagement level of the control group. 
$\mathrm{H} 1$ : The engagement level of the talent group is different from the engagement level of the control group.

While the mean of the engagement in the Talent group is 3.5429 ( $X=3.5429$; S.D.= $0.5678)$, the mean of the control group is $3.6676(\bar{X}=3.6676 ; S . D .=0.73079)$, so the engagement level of the control group is higher than the talent group, but this surplus is not statistically significant (Table 3 ). Thus, it reveals that the engagement level of the talent group is not different from the engagement level of the control group.

The second analysis aims to explore the difference between talent groups before and after the manipulation by the talent management practices. A difference is measured in the talent group after implementing talent management by employing the independent samples test.

$\mathrm{HO}$ : The engagement level of the talent group is not different after the intervention.

$\mathrm{H} 1$ : The engagement level of the talent group is different after the intervention.

The mean of the engagement in the Talent group before the intervention is 3.5429 $((\bar{X}=3.5429 ;$ S.D. $=0.5678)$; after the intervention, average engagement in the talent increases to $4.12(\bar{X}=4.12 ; S . D .=0.52337$ ) (Table 4). An increase was noticed due to the mean comparison, and test results indicate that it is statistically significant (Table 5).

Table 4. Group Statistics of Talent Group in Engagement Before and After the Intervention

\begin{tabular}{cccccc}
\hline Group & $\mathrm{N}$ & Mean & Std. Deviation & Std. Error Mean \\
\hline \multirow{2}{*}{ Engagement } & Talent Group Pre-test & 35 & 3.5429 & 0.56708 & 0.09585 \\
\cline { 2 - 6 } & Talent Group Post-test & 25 & 4.1200 & 0.52337 & 0.10467 \\
\hline
\end{tabular}

Table 5. Independent Samples Test of Engagement for Talent Groups After the Intervention

\begin{tabular}{|c|c|c|c|c|c|c|c|c|}
\hline $\begin{array}{r}\text { Leven } \\
\text { Equality }\end{array}$ & $\begin{array}{l}\text { 's Test for } \\
\text { of Variance }\end{array}$ & & & t-test & for Equality & of Means & & \\
\hline & F Sig. & $T$ & df & $\begin{array}{l}\text { Sig. (2- } \\
\text { tailed) }\end{array}$ & $\begin{array}{c}\text { Mean } \\
\text { Difference }\end{array}$ & $\begin{array}{l}\text { Std. Error } \\
\text { Difference }\end{array}$ & $\begin{array}{r}95 \% \text { Con } \\
\text { Interval } \\
\text { Differ }\end{array}$ & $\begin{array}{l}\text { fidence } \\
\text { lof the } \\
\text { ence }\end{array}$ \\
\hline & & & & & & & Lower & Upper \\
\hline 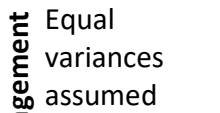 & .910.921 & -4.012 & 58 & .000 & -.57714 & .14387 & -.86513 & -.28916 \\
\hline $\begin{array}{l}\text { Equal } \\
\text { variances not } \\
\text { assumed }\end{array}$ & & -4.066 & 54.217 & .000 & -.57714 & .14193 & -.86167 & -.29261 \\
\hline
\end{tabular}


The third group comparison included both the talent and control groups after the intervention. The comparison results obtained by running the independent samples test revealed a difference between the groups after the intervention. Table 6 indicates the averages of the groups.

Table 6. Group Statistics of Talent and Control Group in Engagement After the Intervention

\begin{tabular}{cccccc}
\hline Group & $\mathrm{N}$ & Mean & Std. Deviation & Std. Error Mean \\
\hline \multirow{2}{*}{ Engagement } & Talent Group Post-test & 25 & 4.12 & 0.52337 & 0.10467 \\
\cline { 2 - 6 } & Control Group Post-test & 33 & 3.7631 & 0.73888 & 0.12862 \\
\hline
\end{tabular}

HO: After the intervention, the engagement level of the talent group is not different from the engagement level of the control group.

$\mathrm{H} 1$ : After the intervention, the engagement level of the talent group is different from the engagement level of the control group.

Accordingly, the independent samples test is provided in Table 7. According to the given results, the average score of the talent group is $4.12(\bar{X}=4.12 ; S . D .=$ $0.52337)$. Furthermore, the average score of the control group is $3.9146(\bar{X}=$ $3.7631 ; S . D .=0.73888$ ) (Table 6). The difference between the groups is statistically significant.

Table 7. Independent Samples Test of Engagement for Talent and Control Groups Post-test

\begin{tabular}{|c|c|c|c|c|c|c|c|c|c|}
\hline \multicolumn{5}{|c|}{$\begin{array}{c}\text { Levene's Test for } \\
\text { Equality of Variances }\end{array}$} & \multicolumn{5}{|c|}{ t-test for Equality of Means } \\
\hline \multirow{2}{*}{\multicolumn{2}{|c|}{$\mathbf{F}$}} & \multirow[t]{2}{*}{ Sig. } & \multirow[t]{2}{*}{$\mathbf{t}$} & \multirow[t]{2}{*}{ df } & \multirow[t]{2}{*}{$\begin{array}{l}\text { Sig. (2- } \\
\text { tailed) }\end{array}$} & \multirow[t]{2}{*}{$\begin{array}{c}\text { Mean } \\
\text { Difference }\end{array}$} & \multirow[t]{2}{*}{$\begin{array}{l}\text { Std. Error } \\
\text { Difference }\end{array}$} & \multicolumn{2}{|c|}{$\begin{array}{l}\text { 95\% Confidence } \\
\text { Interval of the } \\
\text { Difference }\end{array}$} \\
\hline & & & & & & & & Lower & Upper \\
\hline 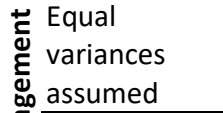 & 3.663 & .061 & 2.054 & 56 & .045 & .35691 & .17374 & .00887 & .70495 \\
\hline 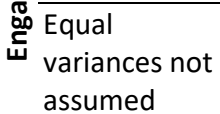 & & & 2.152 & 55.793 & .036 & .35691 & .16583 & .02469 & .68914 \\
\hline
\end{tabular}

The last test for evaluating the difference in engagement covered the control group before and after the intervention (Table 8). The following hypotheses have been tested by performing the independent samples test, and the group averages before and after intervention are provided in Table 9. 
Effects of Talent Management Practices on Organizational Engagement ...

Table 8. Group Statistics of Control Group in Engagement Before and After the Intervention

\begin{tabular}{lccccc}
\hline & Group & $\mathrm{N}$ & Mean & Std. Deviation & Std. Error Mean \\
\hline \multirow{2}{*}{ Engagement } & Control Group Pre-test & 32 & 3.6676 & .73079 & .12919 \\
& Control Group Post-test & 33 & 3.7631 & .73888 & .11769 \\
\hline
\end{tabular}

$\mathrm{HO}$ : After the intervention, the engagement level of the control group is not different.

$\mathrm{H1}$ : After the intervention, the engagement level of the control group is different.

Before the intervention, the mean of the engagement in the control group is 3.6676 $(\bar{X}=3.6676$; S.D.=0.73079); after the intervention, the average engagement in the control group is $3.7631(\bar{X}=3.7631 ; S . D .=0.73888)$ (Table 8). An increase has been noticed due to the mean comparison, but this is not statistically significant (Table 9).

\section{Table 9. Independent Samples Test of Engagement for Control Group} Before and After the Intervention

\begin{tabular}{|c|c|c|c|c|c|c|c|c|c|c|}
\hline & $\begin{array}{c}\text { Levene's } \\
\text { Equality of }\end{array}$ & $\begin{array}{l}\text { Test } f \\
\text { Varia }\end{array}$ & $\begin{array}{l}\text { or } \\
\text { nces }\end{array}$ & & & & t-test fo & r Equality of & f Means & \\
\hline & & $\mathbf{F}$ & Sig. & $t$ & df & $\begin{array}{l}\text { Sig. (2- } \\
\text { tailed) }\end{array}$ & $\begin{array}{c}\text { Mean } \\
\text { Difference }\end{array}$ & $\begin{array}{c}\text { Std. Error } \\
\text { Difference }\end{array}$ & $\begin{array}{r}95 \% \text { Cor } \\
\text { Interva } \\
\text { Differ }\end{array}$ & $\begin{array}{l}\text { fidence } \\
\text { I of the } \\
\text { rence }\end{array}$ \\
\hline & & & & & & & & & Lower & Upper \\
\hline 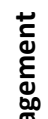 & $\begin{array}{l}\text { Equal } \\
\text { variances } \\
\text { assumed }\end{array}$ & .474 & .494 & -.524 & 63 & .602 & -.09547 & .18233 & -.45983 & .26889 \\
\hline سొ & $\begin{array}{l}\text { Equal } \\
\text { variances not } \\
\text { assumed }\end{array}$ & & & -.524 & 62.974 & .602 & -.09547 & .18230 & -.45977 & .26883 \\
\hline
\end{tabular}

\section{Discussion and Conclusion}

The findings of this research have theoretical and practical contributions.

\subsection{Implications for Theory}

One of the significant findings of this study is regarding the effect of talent management on employees' organizational engagement. The results indicate that the implementation of a talent management program is positively affecting employees' organizational engagement. This finding is consistent with the literature. Several studies conceptually acknowledge the relationship between talent management and employees' organizational engagement (Mohammed, 2015; Pandita \& Ray, 2018; O'Connor \& Crowley-Henry, 2019). There is also a limited number of empirical studies investigating the association of talent management with employees' organizational engagement. For example, Alias et al. (2014) found that 
talent management positively correlates with employees' organizational engagement.

Similarly, Aljunaibi (2014) claims that talent management factors such as talent development, recognition, and leadership support positively correlate with employees' organizational engagement. On the other hand, Goestjahjanti and colleagues (2020) provide empirical evidence regarding the mediating role of employees' organizational engagement between talent management and employees' job satisfaction. However, the findings of this research contribute to the body of literature by providing additional empirical evidence supporting the relationship between TM and employees' organizational engagement.

The study's findings indicate that talent management initiative is embedded within the organizational strategy and can drive organizational change and development. The strategic view of HR suggests that HR strategy should be a part of corporate development and change (Ulrich \& Brockbank, 2005). Accordingly, this study contributes to the literature so that HR can be a part of organizational change and development through talent management and employees' organizational engagement.

As was underlined by Lewis and Heckman (2006), there is still a discrepancy between the practitioner and academic interest in talent management. This study anchored some of the practices with the academic literature, and some theoretical propositions have also been examined.

Another contribution of the study is regarding the research design. This study has contributed via the quasi-experimental desi. In TM field, the number of experimental designs is limited; it may encourage researchers to the extent of the method in this field.

\subsection{Managerial Implications}

Besides its theoretical contributions, the study also has propositions for practitioners and managers. First of all, they should recognize that HR is one of the critical components of value creation, and engaged employees are more likely to contribute to this process. Therefore, implementing talent management programs is an HR tool and should be integrated with organizational strategy. Moreover, being a part of a talent management initiative makes the employees feel more valuable, leading to higher engagement and performance.

Furthermore, talent management initiative is not a simple tool for managers but instead reflects a paradigm change in how they should see and position the employees in an organization. Managers must be aware that new generation employees (millennial employees in particular) are reported to have significantly lower levels of continuance commitment (Glazer et al., 2019). They are frequently asking for more autonomy, respect, and recognition. Additionally, it has been suggested that after the COVID 19 pandemic, a significant change is expected in 
employees' behaviors and expectations (Carnevale, \& Hatak, 2020). Accordingly, managers should initiate TM programs more efficiently and emphasize how to motivate, develop, and retain new talents.

The findings of this study also reveal that the most talented employees are most likely to leave if the TM program is not implemented timely. Therefore the managers should identify the most qualified employees and find out the right TM strategies to develop their talents, make them more engaged and make sure they retain. Finally, it is also essential to keep in mind that TM programs should be implemented to provide individualized consideration. During our research, we have noticed that being selected to a talent pool and engaging in TM activities such as training, mentoring, coaching, etc., make the employees feel unique, distinguished, and more engaged. Particularly for highly talented employees, recognition and individualized consideration are among the most essential issues in TM implementation.

\section{Limitations and Avenues for Future Research}

The scope of the study is the primary limitation of the study. Because of the time and fund constraint, the study was conducted within the administrative departments in the Holding headquarters. It caused to development of a talent pool by a limited number of incumbents. The study can be expanded by enabling the involvement of more incumbents after extending the scope of the task within the holding. The research can also be conducted in different organizations, and both results can be compared and discussed. By doing so, the cultural effect on the process of talent management implementation can be examined, as well.

Another challenge is related to the nature of the study based on the method. This study is an exploratory field study of different units in an organization, and quasiexperimental research was designed for this research. The challenge with a single study of one organization is providing data that is relevant to other situations. Therefore, it is not possible to generalize the results of the investigation. Eisenhardt (1989) states, "Perhaps, it will help others become informed consumers of the results" (p. 549). The data and results can stimulate other theories and research. Yin (2003) points out, "it is the multiple sources of evidence in a real-life case study that is representative or typical that can then be learned and applied to a larger context. Thus, the results are not generalizable, but it calls the new studies to the extent and examines the found results".

The study was performed by implementing the talent management practices, but it was impossible to implement all the proposed actions as expected because of the resource limitation. Therefore, the study has implemented all the necessary practices, and the measurement operated after implementing all possible and allowed procedures as a whole. If the measurement is performed after each application separately, it might be possible to find the effects of each talent management practice on engagement. It may ensure to learn the most effective method of talent management associated with engagement. 


\section{References}

Al Ariss, A., Cascio, W. F., \& Paauwe, J. (2014). Talent management: Current theories and future research directions. Journal of World Business, 49(2), 173-179. http://doi.org/10.1016/i.jwb.2013.11.001

Alias, N. E., Noor, N., \& Hassan, R. (2014). Examining the mediating effect of employees' organizational engagement on the relationship between talent management practices and employee retention in the Information and Technology (IT) organizations in Malaysia. Journal of Human Resources Management and Labor Studies, 2(2), 227-242.

Alias N. E., Nor N. M., Hassan R. (2016) The Relationships Between Talent Management Practices, Employee Engagement, and Employee Retention in the Information and Technology (IT) Organizations in Selangor. In: J. Pyeman, W. Wan Rashid, A. Hanif, S. Syed Mohamad, P. Tan (eds) Proceedings of the 1st AAGBS International Conference on Business Management 2014 (AiCoBM 2014). Springer, Singapore. https://doi.org/10.1007/978-981-287-426-9 9

Aljunaibi, M. M. (2014). Talent management and employees' organizational engagement [Doctoral dissertation, The British University in Dubai (BUiD)].

Axelrod, B., Handfield-Jones, H., Welsh, T., (2001). War for talent, part two. McKinsey Quarterly 2, 9-11

Azmi, F. T., (2008). From Picnic Organizers to Strategists: Turn of the Wheel for Human Resource Managers, Eurasian Journal of Business and Economics, 1 (1), 37-60.

Bakker, A.B., Demerouti, E., De Boer, E. and Schaufeli, W.B. (2003). Job Demands and Job Resources as Predictors of Absence Duration and Frequency. Journal of Vocational Behavior, 62(2), 341-356. http://dx.doi.org/10.1016/S0001-8791(02)00030-1

Bakker, A. B., Schaufeli, W. B., Leiter, M. P., \& Taris, T. W. (2008). Work engagement: An emerging concept in occupational health psychology. Work \& Stress, 22(3), 187-200. http://doi.org/10.1080/02678370802393649

Barney, J. B., \& Wright, P. M. (1998). On becoming a strategic partner: The role of human resources in gaining competitive advantage. Human Resource Management, 37(1), 31-46. http://doi.org/10.1002/(SICl)1099-050X(199821)37:1<31::AID-HRM4>3.0.CO;2-W

Barrick, M., Thurgood, G., Smith, T. A., \& Courtright, S. H. (2015). Collective Organizational Engagement: Linking Motivational Antecedents, Strategic Implementation, and Firm Level Performance. Academy of Management Journal, 58(1), 111-135. http://doi.org/10.5465/ami.2013.0227

Berger, L., \& Berger, D. (2004). The talent management handbook. New York. Retrieved from http://www.transformhr.net/pdf files/book successor.pdf

Bhatnagar, J. (2007). Talent management strategy of employees' organizational engagement in Indian ITES employees: Key to retention. Employee Relations, 29(6), 640-663. http://doi.org/10.1108/01425450710826122

Blass, E. (2007). Talent Management: Maximising talent for business performance. Executive Summary November 2007, 1-12. https://www.bl.uk/collection-items/talent-managementmaximising-talent-for-business-performance\#

Blass, E. (2009). Talent management: cases and commentary. Palgrave Macmillan.

Boudreau, J. W., \& Ramstad, P. M. (2004). Talentship and Human Resource Measurement and Analysis: From ROI to Strategic Organizational Change. The University of Southern California, 6(September), 0-12. 
Effects of Talent Management Practices on Organizational Engagement ...

Brown, T. A. (2006). Confirmatory factor analysis for applied research (2nd ed.). The Guilford Press.

Butler, T. \& Waldroop, J. (2004). Understanding "people" people. Harvard business review. 82. 78-86, 136.

Carnevale, J. B., \& Hatak, I. (2020). Employee adjustment and well-being in the era of COVID19: Implications for human resource management. Journal of Business Research, 116, 183187. https://dx.doi.org/10.1016\%2Fj.jbusres.2020.05.037

Chambers, E. G., Foulon, M., Handfield-jones, H., Hankin, S. M., \& lii, E. G. M. (1998). The War for Talent. The McKinsey Quarterly, (3), 44-58.

Christian, M. S., Garza, A. S., \& Slaughter, J. E. (2011). Work engagement: A quantitative review and test of its relations with task and contextual performance. Personnel Psychology, 64(1), 89-136. https://doi.org/10.1111/i.1744-6570.2010.01203.

Collings, D. G., \& Mellahi, K. (2009). Strategic talent management: A review and research agenda. Human Resource Management Review, 19(4), 304-313. https://doi.org/10.1016/j.hrmr.2009.04.001

Dahou, Khadra \& Hacini, Ishaq. (2018). Successful Employee Empowerment: Major Determinants in the Jordanian Context. Eurasian Journal of Business and Economics. 11. 4968. https://doi.org/10.17015/ejbe.2018.021.03

Esen, E. (2012). The role of trust on the relationship between organizational engagement and corporate reputation. Journal of Management \& Economics, 19(1), 47-58.

Eisenhardt, K. M. (1989). Building theories from case study research. Academy of Management Review, 14, 532-550.

Gable, G.G. (1994). Integrating Case Study and Survey Research Methods: An Example in Information Systems. European Journal of Information Systems, 3(2), 112-126.

Gallardo-Gallardo, E., Thunnissen, M., Scullion, H. (2020) Talent management: context matters, The International Journal of Human Resource Management, 31(4), 457-473 https://doi.org/10.1080/09585192.2019.1642645

Glazer, S., Mahoney, A. C. \& Randall, Y. (2019), Employee development's role in organizational commitment: a preliminary investigation comparing generation $\mathrm{X}$ and millennial employees, Industrial and Commercial Training, 51(1), 1-12. https://doi.org/10.1108/ICT-072018-0061

Glavas, A. (2012). Employees' organizational engagement and Sustainability: A Model for Implementing Meaningfulness at and in Work. Journal of Corporate Citizenship, 46, 13-29.

Goestjahjanti, S. F., Novitasari, D., Hutagalung, D., Asbari, M., \& Supono, J. (2020). Impact of Talent Management, Authentic Leadership and Employees' organizational engagement on Job Satisfaction: Evidence From South East Asian Industries. Journal of Critical Reviews, 7(19), 6788. https://doi.org/10.31838/jcr.07.19.8

Groves, K. S. (2011). Talent management best practices: how exemplary health care organizations create value in a down economy. Health Care Management Review, 36(3), 227240. http://doi.org/10.1097/HMR.0b013e3182100ca8

Hadziahmetovic, N., Dinc, M. S., \& Jahic, K. (2017). A Research Review of MotivationEnhancing of Human Resource Practices. Journal of Eastern European and Central Asian Research (JEECAR), 4(2), 20. https://doi.org/10.15549/jeecar.v4i2.163 
Hallberg, U. E., \& Schaufeli, W. B. (2006). "Same same" but different? Can work engagement be discriminated from job involvement and organizational commitment? European Psychologist, 11(2), 119-127. http://doi.org/10.1027/1016-9040.11.2.119

Harsch, K, Festing, M. (2020). Dynamic talent management capabilities and organizational agility-A qualitative exploration. Human Resource Management, 59(1), 43- 61. https://doi.org/10.1002/hrm.21972

Heinen, J. S., \& O'Neill, C. (2004). Managing talent to maximize performance. Employment Relations Today, 31(2), 67-82. http://doi.org/10.1002/ert.20018

Hughes, J. C., \& Rog, E. (2008). Talent management: A strategy for improving employee recruitment, retention and engagement within hospitality organizations. International Journal of Contemporary Hospitality Management, 20(7), 743-757. http://doi.org/10.1108/09596110810899086

Iles, P., Chuai, X., \& Preece, D. (2010). Talent Management and HRM in Multinational companies in Beijing: Definitions, differences and drivers. Journal of World Business, 45(2), 179-189.

Kahn, W. A. (1990). Psychological Conditions of Personal Engagement and Disengagement at Work, Academy of Management Journal, 33(4), 692-724.

Kahn, W. A. (1992). To Be Fully There: Psychological Presence at Work. Human Relations, 45(4), 321-349. https://doi.org/10.1177/001872679204500402

Lado, A .A., \& Wilson, M.C. (1994). Human Resource Systems and Sustained Competitive Advantage: A Competency-Based Perspective, The Academy of Management Review, 19(4), 699-727. https://doi.org/10.5465/amr.1994.9412190216

Lewis, R. E., \& Heckman, R. J. (2006). Talent management: A critical review. Human Resource Management Review, 16(2), 139-154. http://doi.org/10.1016/i.hrmr.2006.03.001

Lockwood, N. R. (2007). Leveraging Employees' organizational engagement for Competitive Advantage. Research Quarterly, 52(3), 1-12. https://doi.org/10.1109/HICSS.2007.324

Macey, W. H., \& Schneider, B. (2008). The Meaning of Employees' organizational engagement. Industrial and Organizational Psychology, 1(1), 3-30. https://doi.org/10.1111/i.17549434.2007.0002.x

Mattone, J., \& Xavier, L. F. (2012). Talent leadership: A proven method for identifying and developing high-potential employees. New York: American Management Association.

Mohammed, A. (2015). The impact of talent management on employees' organizational engagement, retention and value addition in achieving organizational performance. International Journal of Core Engineering \& Management (IJCEM), 1(12), 1-4.

Nonaka, I. (Ed.). (2005). Knowledge management: critical perspectives on business and management (Vol. 2). Taylor \& Francis.

O'Connor, E. P., \& Crowley-Henry, M. (2019). Exploring the relationship between exclusive talent management, perceived organizational justice and employees' organizational engagement: Bridging the literature. Journal of Business Ethics, 156(4), 903-917. https://doi.org/10.1007/s10551-017-3543-1

Pandita, D., \& Ray, S. (2018). Talent management and employees' organizational engagementa meta-analysis of their impact on talent retention. Industrial and Commercial Training, 50(4), 185-199. https://doi.org/10.1108/ICT-09-2017-0073 
Robinson, D., Perryman, S. and Hayday, S. (2004) The Drivers of Employees' organizational engagement. Report 408. Institute for Employment Studies, UK.

https://www.employment-studies.co.uk/system/files/resources/files/408.pdf

Saks, \& M., A. (2006). Antecedents and consequences of employees' organizational engagement. Journal of Managerial Psychology, 21(7), 600-619. http://doi.org/10.1108/02683940610690169

Sambrook, S. A., Jones, N., \& Doloriert, C. (2014). Employees' organizational engagement and autoethnography: being and studying self. Journal of Workplace Learning, 26(3), 172-187. http://doi.org/10.1108/JWL-09-2013-0072

Saunders, M., Lewis, P., \& Thornhill, A. (2009). Research Methods for Business Students (5th Ed.). London: Pearson Education.

Schaufeli, W.B. and Bakker, A.B. (2004), Job demands, job resources, and their relationship with burnout and engagement: a multi-sample study. Journal of Organizational Behavior, 25(3), 293-315. https://doi.org/10.1002/job.248

Schaufeli, W. B. (2006). The Measurement of Work Engagement With a Short Questionnaire: A Cross-National Study. Educational and Psychological Measurement, 66(4), 701-716. http://doi.org/10.1177/0013164405282471

Schiemann, W. A. (2014). From talent management to talent optimization. Journal of World Business, 49(2), 281-288. http://doi.org/10.1016/i.jwb.2013.11.012

Shuck, B., Reio Jr, T.G., Rocco, T.S. (2011) Employees' organizational engagement: An examination of antecedent and outcome variables, Human Resource Development International, 14(4), 427-445. https://doi.org/10.1080/13678868.2011.601587

Sekaran, U. (2003). Research Methods for Business: A Skill-Building Approach. 4th Edition, John Wiley \& Sons, New York.

Sparrow, P. \& Hird, M. \& Balain, S. (2011). Talent Management: Time to Question The Tablets Of Stone? Centre for Performance-led HR White Paper 11/01. Lancaster University Management School. https://doi.org/10.13140/RG.2.1.3991.7044

Sparrow, P. and Scullion, H. and Tarique, I. (2014). Strategic Talent Management: Contemporary Issues in International Context, Cambridge University Press.

Tetik, S. (2016). Talent Management: A Review of Theoretical Perspectives and a Guideline for Practitioners. Nile Journal of Business and Economics, (4), 40-56. https://doi.org/10.20321/nilejbe.v2i4.77

Thunnissen, M., Boselie, P., \& Fruytier, B. (2013). Talent management and the relevance of context: Towards a pluralistic approach. Human Resource Management Review, 23(4), 326336. http://doi.org/10.1016/j.hrmr.2013.05.004

Ulrich, D., \& Brockbank, W. (2005). The HR value proposition. Harvard Business Press.

Waheed, S., Zaim, A., \& Zaim, H. (2012). Talent Management in Four Stages. The USV Annals of Economics and Public Administration, 12(1), 130-137.

Yin, R.K. (2003). Case Study Research: Design and Methods. Sage. Thousand Oaks, California.

Zaim, H., Keceli, Y., Jaradat, A. and Kastrati, S. (2018). The effects of knowledge management processes on human resource management: Mediating role of knowledge utilization. Journal of Science and Technology Policy Management, 9(3), 310-328. https://doi.org/10.1108/JSTPM-02-2018-0011 


\section{Appendices}

\section{Appendix 1. Talent Matrix}

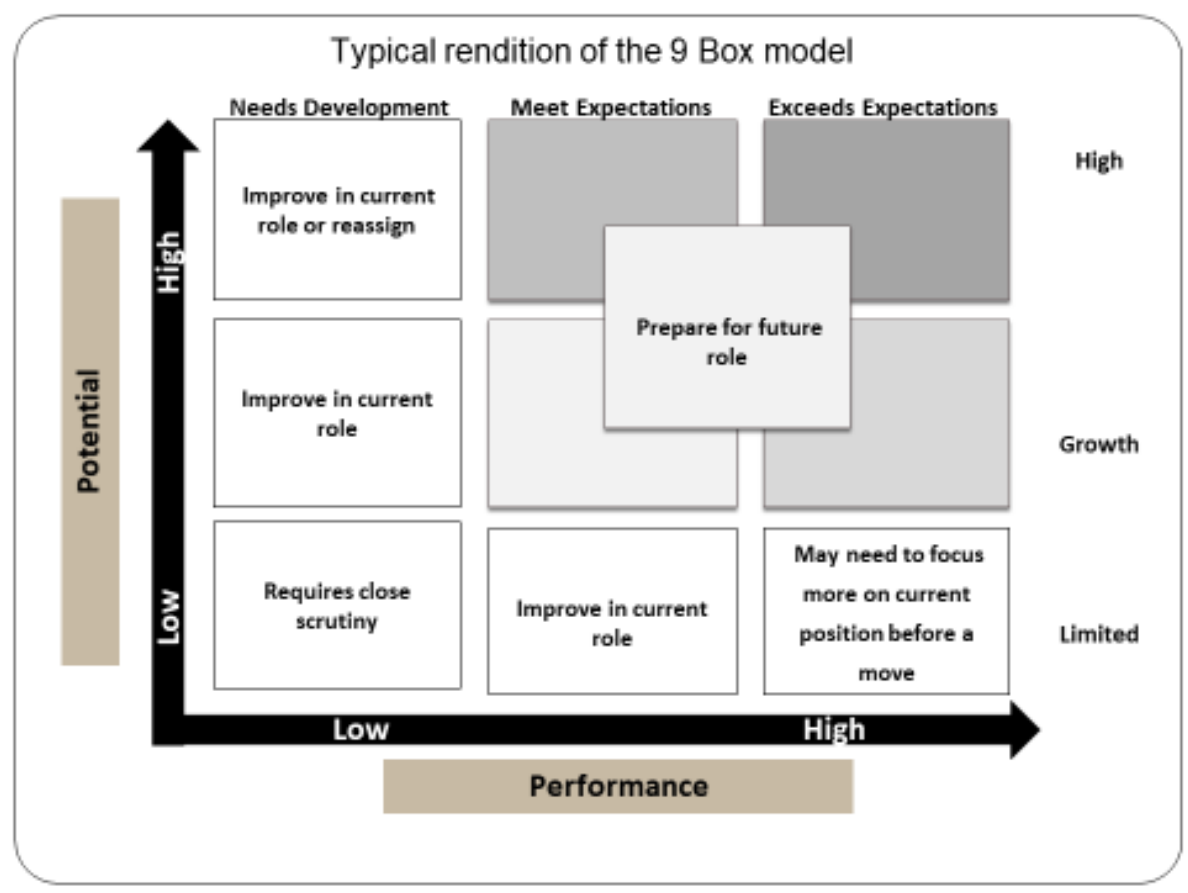

Figure A1. Talent Matrix

Source: Sparrow et al. (2011)

\section{Appendix 2. Talent Grid}

Four of the incumbents were assessed as ready for promotion; four incumbents can be promoted in the short-term; six incumbents can be promoted in the intermediateterm, and two can be considered long-term for the promotion. Generally, all the participants were taken in promotion bench who were evaluated as stars and rising stars. After mapping the talent code of the participants on the grid, a development path will be constructed. 
Effects of Talent Management Practices on Organizational Engagement ...

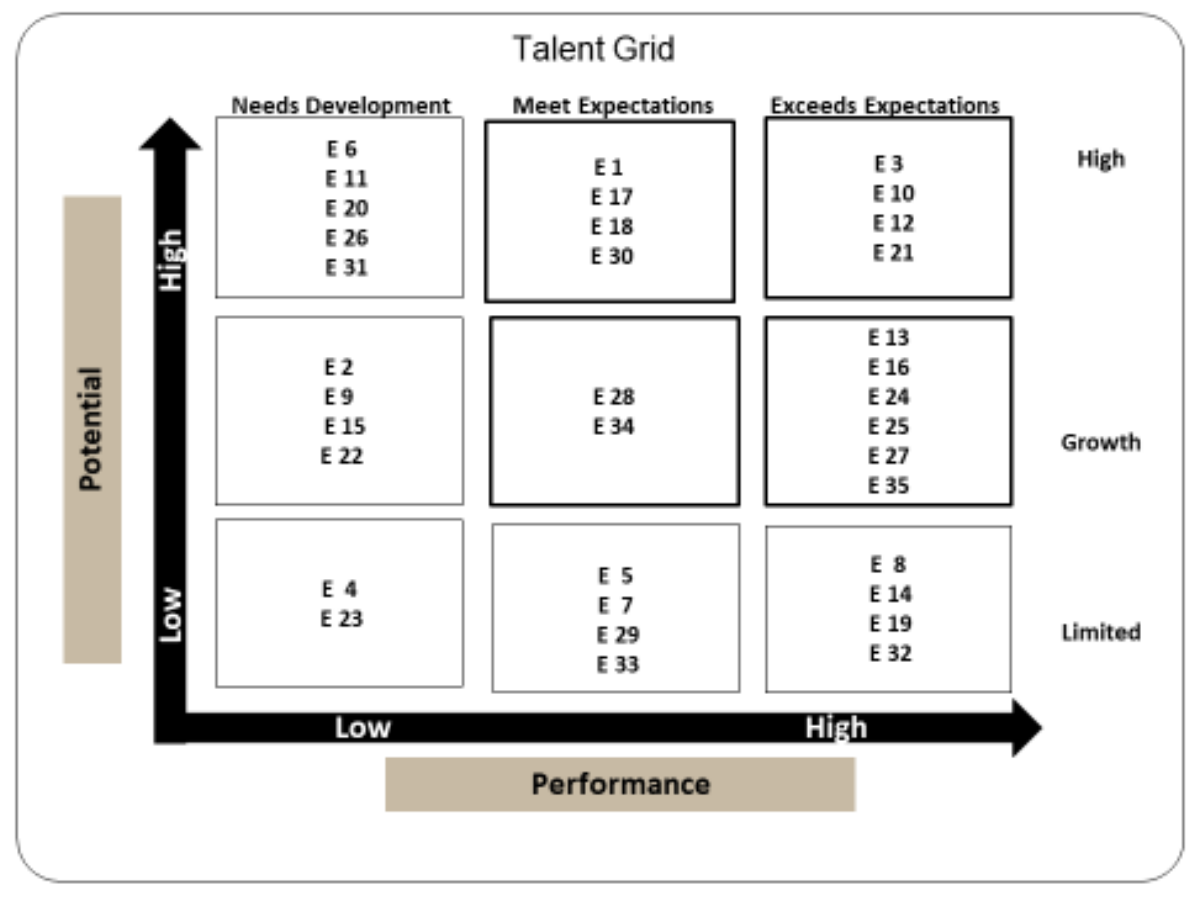

Figure A2. Talent Grid 